\title{
The interaction of flow regimes and nutrient fluxes on the water quality and ecosystem health of a clear, freshwater wetland
}

\author{
Margaret Shanafield $^{1}$, Anna Rigosi ${ }^{2}$, Yang Liu $^{2}$ and $\underline{\text { Justin Brookes }}^{2}$
}

\begin{abstract}
Across the globe, the hydrology and ecology of wetland systems have been altered by anthropogenic activities, sometimes leading to regime shift or even ecosystem collapse. Often, it is not only the impact of one stressor, but the combination of multiple stressors interacting that ultimately leads to adverse ecological impact in wetland systems. However, because of the difficulty in measuring the combined, dynamic effects of multiple stressors, relatively few studies estimate the relative importance of multiple stressors on wetland ecosystems. We combined controlled laboratory and field experiments with a modeling exercise to examine the relative importance of flow and nutrient loads on the resilience of a clear, groundwater-fed wetland dominated by macrophytes. We examined the potential for a combination of lower inflow and higher nutrient loads to increase phytoplankton growth and reduce light availability, culminating in a reduction in macrophyte growth due to the shading of the phytoplankton. This combination of events could result in a collapse of this endemic ecosystem, including local extinction of several endangered species. We found that the resilience of the macrophyte-dominated wetlands is maintained by preserving high flow even under increasing phosphorus concentrations. Nutrient availability increases as flow decreases, favoring pelagic algal development and inducing a shift in the ecosystem conditions. This shows that focusing only on input nutrient levels, as is often done in open waters of concern, is not sufficient to preserve the native ecosystem and highlights the need to consider multiple factors when assessing anthropogenic impacts on wetlands.
\end{abstract}

Key Words: agricultural withdrawal; ecosystem resilience; nutrient thresholds; stressor interaction; wetland conservation

\section{INTRODUCTION}

Global estimates put long-term wetland loss at $54-57 \%$ since the beginning of the $18^{\text {th }}$ century and show that the rate of wetland loss in the past two centuries has accelerated; $64-71 \%$ of wetlands have disappeared since 1900 (Davidson 2014). Wetlands have been replaced by airports, agricultural land, cities, and golf courses. Many of the world's remaining wetlands are in danger because of increasing water use in the surrounding areas. In areas of agricultural development, such as in many developing countries in Asia, the environmental impacts of drainage on wetlands are high and the rate of wetland loss is even greater (Blann et al. 2009, Davidson 2014). Protection of remaining wetlands relies on human perception of the value of a given wetland, both economically and for its multifunctionality (Mitsch and Gosselink 2000).

The effects of specific anthropogenic alterations to wetland systems have been recognized. For example, the change of nutrient sources related to agriculture has been one of the most important causes of reducing freshwater system resilience (Carpenter and Cottingham 1997). It is now well understood that wetlands act as nutrient sinks for surrounding agriculture; in some cases, so-called "treatment wetlands" are even constructed to absorb and remove excess agricultural nutrient loads (Verhoeven et al. 2006). Additionally, the depletion of groundwater reserves to satisfy multiple anthropogenic activities affects the functioning and health of both groundwater and surface waters (Danielopol et al. 2003). Fresh (not saline), groundwater-fed wetlands are especially vulnerable to the multiple impacts of drainage, water extraction, and agricultural pollution, which represent a global scale problem (Lemly et al. 2000).
Ecosystem changes can occur gradually over time, or populations may shift abruptly, with the likelihood of the shift increasing as conditions approach a tipping point (Scheffer and Carpenter 2003, Scheffer et al. 2012). Therefore, it is important to identify the reaction of a population to specific stressors on its environment and understand how multiple stressors can affect its resilience and limits. However, despite many previous studies on the anthropogenic impacts to wetland systems, our understanding of the interaction of multiple stressors in natural waters is still limited because only a few studies examine how a combination of factors may control changes in freshwater ecosystem health (Hipsey et al. 2015). For example, Gunn et al. (2001) examined the combined impacts of climate change, increasing UV exposure, and acidification on clear water lakes in Canada. Paerl and Scott (2010) discussed the combinations and mechanisms of nutrient loading that can lead to cyanobacterial blooms in lakes, as well as the role of climate change in providing additional stressors. Combinations of hydrologic alterations and nutrient dynamics associated with changes in land use have also been shown to shift shallow lake conditions from a clear-water, macrophytedominated state to a turbid, phytoplankton-dominated state (Scheffer and Carpenter 2003, Ibelings et al. 2007). Finally, changes in hydrology and rates of hydrodynamic disturbance can combine to alter phytoplankton community succession (Reynolds 1993, Elliott 2010); the rate of flushing can also control the maximum achievable biomass.

In the context of understanding the relative importance of hydrodynamics (in this case flow) and nutrients in maintaining a clear water environment, we describe an approach which combines experimental, field, and modeling to test the relative importance of inflow volume and nutrient loads in inducing

${ }^{1}$ Flinders University, College of Science and Engineering, Adelaide, Australia, ${ }^{2}$ The University of Adelaide, School of Biological Sciences, Water Research Centre, Adelaide, Australia 
ecosystem shift from a clear, macrophyte-dominated wetland system to a phytoplankton-dominated system. Ewens Ponds is a wetland system in an important ecological and tourism site that attracts approximately 10,000 divers a year to an otherwise agricultural region of Southeast South Australia, and is home to a threatened, endemic ecosystem. Increased use of center pivot irrigation in the region (which uses high volumes of groundwater), combined with a long-term trend in increasing nutrient application and resulting pollution of the unconfined groundwater aquifer, has led to concerns over the wetland health. Therefore, we hypothesized that a combination of groundwater inflow and nutrient load controls water clarity and ecosystem health. To test this hypothesis, we had three objectives: (1) to develop water and nutrient budgets for Ewens Ponds; (2) to determine the factors controlling phytoplankton growth in Ewens Ponds; and (3) to identify the nutrient and flow thresholds needed to maintain the water clarity and determine how this affects the depth distribution of submerged macrophytes. The first objective was achieved through collection of field data, which were used to understand daily and seasonal variability of water and nutrient fluxes into and through the ponds in a mass balance approach. To meet the second objective, sediment nutrient fluxes and sediment oxygen demand were estimated from laboratory experiments and used to estimate future nutrient inputs coming from the sediments. Macrophyte light climate experiments were performed in the laboratory to determine photosynthesis in response to light intensity. Dating of groundwater from inflows to the ponds and from wells adjacent to the ponds was used to estimate potential future nutrient loads for the system. Finally, the third objective was achieved through parameterization of a phytoplankton growth and dilution model. Phytoplankton incubations (bioassays) at different nutrient levels were used to calculate algae growth rates for input to the model. The maximum depth of colonization $\left(\mathrm{z}_{\mathrm{col}}\right)$ is an important parameter to assess light requirements (Kirk 2011). We considered a shift in the light dose of $1 \mathrm{~m}$ (i.e., $9-17 \%$ of the total pond depth) to be a drastic reduction in available macrophyte habitat in this shallow system and therefore used this modeling exercise to identify the criteria under which the light dose would reach $1 \mathrm{~m}$ shallower than under current conditions.

\section{METHODS}

\section{Study site}

Ewens Ponds are located in the Lower Limestone Coast of South Australia, approximately $30 \mathrm{~km}$ south of the city of Mt Gambier (Fig. 1). They consist of three karst wetlands connected by channels that feed into Eight Mile Creek, which discharges to the sea approximately $2.5 \mathrm{~km}$ downstream. The 3 ponds (ponds 1, 2, and 3) have a maximum depth of $11 \mathrm{~m}, 6 \mathrm{~m}$, and $9 \mathrm{~m}$, respectively, and volumes of approximately $28,000 \mathrm{~m}^{3}, 11,000 \mathrm{~m}^{3}$, and 4400 $\mathrm{m}^{3}$ (Grandfield and Ashman 1984). Ewens Ponds are spring-fed, and groundwater can be seen bubbling into the ponds through the bottom sediments. There are two major aquifers underlying the ponds: the upper unconfined Tertiary Limestone Aquifer and the lower Tertiary Confined Sand Aquifer (Mustafa et al. 2012). The unconfined aquifer is up to $300 \mathrm{~m}$ thick near the coast, consists of three main subaquifers, and is used extensively for agricultural withdrawal in the region (Wood 2011). The unique features of Ewens Ponds support several vulnerable and endangered species of aquatic fauna and flora including Ewens pygmy perch (Nannoperca variegata), river blackfish (Gadopsis marmoratus), Glenelg spiny crayfish (Euastacus bispinosus), burrowing crayfish (Engaeus strictifrons), and freshwater crayfish (Geocharax sp.; National Parks and Wildlife South Australia 1999). Thousands of divers visit Ewens Ponds annually; recent observations of algal blooms (Carmody 2006) suggest a change in water quality that would not only affect the health of this ecosystem, but also result in lower recreational value for visitors.

Fig. 1. Map of study area, including (A) locations of Ewens Ponds (red star) in South Australia (shaded green); (B) location of ponds in relation to bores (MAC045, MAC093/094, MAC030, CAR004, MAC025); and (C) inset of ponds and flowmeter.

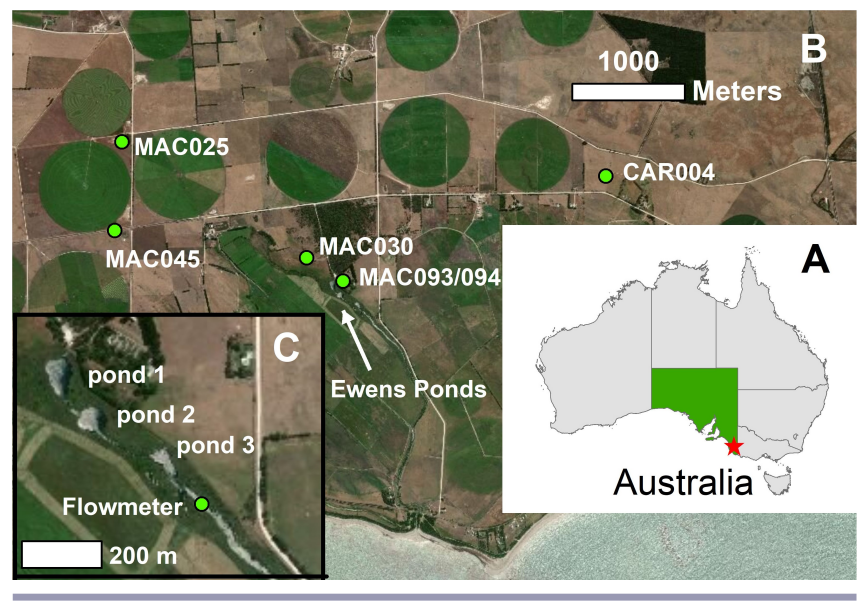

\section{Water and nutrient budgets determined from field surveys}

Sample collection and analysis

Field investigations were conducted in May, July, September, and December 2014 and in January 2015 to measure flow through the ponds and to sample nutrient concentrations in each pond. Measurement of inflow to the ponds was challenging because there was no surface inflow; the ponds are fed by groundwater through many vents. It was assumed that there was no loss to groundwater and so the daily surface outflow was equal to daily groundwater inflow. Flow measurements were taken at the outflow of each pond in May 2014 using a StreamPro (Teledyne RDI; Poway, California), an Acoustic Doppler Current Profiler (ADCP), downward mounted on a floating platform. Although the point measurement provided a good starting point, time-series information on the flow through the ponds was desired. Therefore, to measure change in flow over time, pressure, and specific conductivity, probes (TROLL loggers, In-Situ, Fort Collins, Colorado) were deployed in each pond $2 \mathrm{~m}$ below the surface and downstream of pond 3 , recording every 30 minutes. Barometric measurements collected directly adjacent to the ponds were used to correct the recorded pressures in the ponds. A flow meter (Starflow, Flow Recorder Model 6526) was deployed at the outflow of pond 3 and recorded flow velocity every 30 minutes (Fig. 1). The assumption that the ponds were fully mixed (and therefore the specific conductivity measured in each pond was indicative) was monitored using thermistors deployed in each of the ponds. 
Discrete water samples were collected for nutrient analysis during each field investigation from the surface and $4 \mathrm{~m}$ below the surface of each pond. Samples of the groundwater entering the ponds were collected where water was observed to be flowing in through the sediment in May 2014 and in January 2015. Samples from bores MAC 045 and MAC 093/094 were collected during each field investigation after first pumping to purge stagnant borehole water until a constant $\mathrm{pH}$ value was observed; at the beginning of September 2014 after a rainfall event $(\sim 10 \mathrm{~mm})$, bore samples were collected at three additional bores within $2 \mathrm{~km}$ of the ponds for comparison (Fig. 1). All samples were kept on ice following collection and returned to the laboratory. Total nitrogen (TN), total phosphorus (TP), nitrate $\left(\mathrm{NO}_{3}\right)$, nitrite $\left(\mathrm{NO}_{2}\right)$, orthophosphate $\left(\mathrm{PO}_{4}\right)$, and ammonia $\left(\mathrm{NH}_{4}\right)$ were determined from water samples using standard methods (APHA 2005) at the accredited laboratory at Southern Cross University.

\section{Water budget}

The water budget was calculated by adopting a mass balance approach accounting for the major inputs and outputs (e.g., Owen 1995, Windolf et al. 1996, Yin and Nicholson 1998):

Change in pond volume over time $=$ inflow $($ surface + groundwater) + precipitation - evaporation - outflow (groundwater + surface) (Eqn. 1)

A meteorological station from nearby Mt Gambier provided precipitation and evaporation data (station 026021, Bureau of Meteorology, Commonwealth of Australia). Loss of water from the ponds to the groundwater was assumed to be negligible, given the high flow of groundwater into the ponds. Additional assumptions used to estimate groundwater inflows were: no change in lake volume over time, no surface inflow to any of the ponds, and the flow into ponds 2 and 3 was equal to the outflow of ponds 1 and 2, respectively. Therefore, the final water balance equation was:

Change in pond volume over time $=$ groundwater inflow + precipitation - evaporation - surface outflow (Eqn. 2)

\section{Nutrient budget}

The nutrient budget was calculated following Nõges et al. (1998), where the net budget is the sum of the internal and external budget:

External budget $=$ external loading (riverine + atmospheric + groundwater) - outflow (Eqn. 3)

Internal budget $=(\text { concentration } * \text { volume })_{\text {time }}$ (concentration * volume) $)_{\text {time-1 }}$ (Eqn. 4)

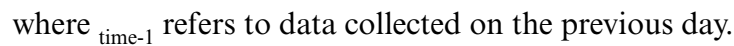

Because of the low retention time, a well-oxygenated inflow, and a fully mixed water column, the internal nutrient load at daily time scale was assumed to be negligible under these circumstances and set to zero. The atmospheric contribution was considered negligible and the riverine contribution was zero for pond 1 and equal to the outflow of the preceding pond for ponds 2 and 3 (as for the surface inflow in the water budget). The net nutrient input was then assumed to be equal to the external nutrient input from the groundwater inflow calculated from the water budget. The mean nutrient concentration observed in all the ponds at the time of monitoring was used as the input concentration, because due to the high groundwater flow and mixing, it was the most representative of the daily input.

\section{Field and laboratory experiments}

\section{Sediment nutrient fluxes and sediment oxygen demand}

Experiments on nutrient sediment flux were used to evaluate possible internal nutrient inputs if the water column became stratified. A total of 13 intact sediment cores were collected on 29 May 2014 using unsealed cylindrical chambers with an internal diameter of $0.058 \mathrm{~m}$ attached to a pole and pushed $0.1-0.15 \mathrm{~m}$ into the sediment, then sealed and extracted, and kept on ice for transport to the laboratory. Cores deeper than $4 \mathrm{~m}$ were collected manually by divers. At pond 1 , three replicates at $4 \mathrm{~m}$ depth and two at $8 \mathrm{~m}$ were collected. At pond 2, two replicates were collected at $4 \mathrm{~m}$ depth and two at $4.5 \mathrm{~m}$ depth. At pond 3, two replicates at $4 \mathrm{~m}$ depth, one at 4.5 , and one at $8 \mathrm{~m}$ were collected. All cores were incubated in the dark at $20^{\circ} \mathrm{C}$ and sediment oxygen demand was determined by measuring dissolved oxygen (DO) every 30 minutes with a dissolved oxygen probe (Model WP-82). Sediment oxygen demand was calculated as the change in DO (mass) per unit surface area, per unit time over the first 24 hours. Nutrient flux rates (total phosphorus and orthophosphate) were determined after five days of incubation from the change in concentration in the overlying water. Standard errors were calculated considering the standard deviation of the nutrient concentrations measured at the initial conditions.

To test differences between sediment oxygen demand and nutrient fluxes measured in different ponds, one-way analysis of variance (ANOVA; SPSS, IBM) was conducted. To test symmetry of data, the Levenes' homogeneity-of-variance test was used. Tukeys' post-hoc test was used to determine sources of significant differences between parameters. When the homogeneity-ofvariance assumption was violated, an alternative nonparametric test, the Friedman test, was used.

\section{Macrophyte light climate}

Field incubations in chambers were used to estimate primary productivity of macrophytes at different light conditions. Three $0.35 \mathrm{~m}$ diameter clear Perspex domes with lids were positioned on top of the sediment colonized by macrophytes in pond 1 at approximately $4 \mathrm{~m}$ depth. Domes were deployed at 12:30 p.m., 20 January 2015 for 28 hours. The water inside the domes was mixed with a submersible pump and changes in dissolved oxygen (DO) were measured at one-minute intervals with an optical dissolved oxygen sensor (D-02 D-opto Logger). Domes were flushed twice during the day to avoid super saturation of oxygen. Photosynthetically active radiation was recorded every five minutes at the surface and underwater at the chamber's depth, using a data logger LI-1400 and an Odyssey logger (Dataflow Systems, Environmental Monitoring), respectively. Incubations were carried out for one day and one night to enable calculation of productivity and respiration. Respiration was calculated as the difference between DO concentration at the beginning and end of dark period $\left(\mathrm{mg} \mathrm{O}_{2} \mathrm{~L}^{-1} \mathrm{~h}^{-1}\right)$ and gross primary productivity was the difference during light periods. Net productivity was estimated for each hour as the difference between gross productivity and respiration averaged during the night (Nöel et al. 2010). To standardize the results, the net productivity was corrected for unit 
of biomass ( $\mathrm{mg} \mathrm{O}_{2} \mathrm{~L}^{-1} \mathrm{~h}^{-1} \mathrm{~g}^{-1}$ ). Macrophyte biomass growing over the surface area covered by the chamber was collected and measured as dry weight. Changes in DO recorded at the different domes were then used to calculate hourly net primary productivity and standardized to biomass of the macrophytes (Charophytes, Ranunculus inundatus) in each dome. Photosynthetically active radiation measured underwater every five minutes was averaged hourly at the same time intervals used for the calculation of net primary production.

\section{Groundwater dating}

Samples were collected 26-30 May 2014, where water was observed to be discharging into ponds from the groundwater, in the channels between ponds, and at the outflow from pond 3 . The samples were collected by opening the glass sample bottles under water at the desired location, then evacuating the bottle using nylon tubing connected to a glass syringe to obtain a clean sample. Samples were also collected at groundwater bores MAC45 and MAC94 (Fig. 1) using a submersible pump connected to nylon tubing. Additionally, samples were collected from two adjacent bores, up-gradient of the ponds in the unconfined aquifer to link the groundwater inflow to this aquifer. Water age was estimated by analyzing chlorofluorocarbons (CFCs), which are commonly used to determine water ages of between 1 and 100 years old (Busemberg and Plummer 1992, Cook et al. 1995). Chlorofluorocarbons are stable, synthetic compounds released into the atmosphere since the 1930s, and for which the atmospheric mixing ratios have been reconstructed over the past 50 years. Samples were analyzed for CFC-11, CFC-12, and CFC-13 at GNS Science (Lower Hutt, New Zealand) using gas chromatography with electron capture detection. Results were converted to equivalent atmospheric partial pressures based on the gas solubility at an assumed recharge temperature and pressure (Cook et al. 1995). Equivalent atmospheric partial pressures, reported as parts per thousand volume (pptv), were converted to apparent recharge years using the historic concentrations of these trace gases in the atmosphere. Among the CFC analyses, CFC-12 provides the most reliable groundwater dating results because it is more stable than CFC-11 and CFC-13 in subsurface environments. Therefore, CFC-12 results are presented in this study. The recharge year represents an apparent groundwater age only because groundwater represents a mix of waters that have recharged over time.

\section{Phytoplankton growth and dilution modeling}

Light availability at different $z_{\text {col }}$ was calculated following the Lambert-Beer law. Average daily light radiation (wavelength range of $300-400 \mathrm{~nm}$ ) measured at the ponds' surface in January $2015\left(380 \mu \mathrm{mol} \mathrm{m}^{-2} \mathrm{~s}^{-1}\right)$ was used as a reference with an extinction coefficient of $0.33 \mathrm{~m}^{-1}$ estimated from irradiance profile measurements in the field.

Two scenarios were simulated using a variety of growth rates and flow rates: the light availability to maintain the growth of macrophyte at the present level and a change in light attenuation that would reduce $\mathrm{z}_{\mathrm{col}}$ by $1 \mathrm{~m}$. Lilaeopsis polyantha grows to approximately $5 \mathrm{~m}$ (Grandfield and Ashman 1984) where the light intensity reaches a mean daily light intensity of $73 \mu \mathrm{mol} \mathrm{m} \mathrm{m}^{-2} \mathrm{~s}^{-1}$ under present conditions. If the turbidity of the water column increased sufficiently to decrease the maximum depth of colonization for macrophytes by $1 \mathrm{~m}$, the mean daily light intensity would be $48 \mu \mathrm{mol} \mathrm{m}^{-2} \mathrm{~s}^{-1}$.
Chlorophyll-a (Chla) concentration thresholds corresponding to the two light levels were calculated considering vertical light attenuation by phytoplankton as follows:

$$
C_{1}=\left(\mathrm{k}_{i}-\mathrm{k}_{w}\right) / \mathrm{k}_{1} \quad(\text { Eqn. 5) }
$$

where $k_{i}$ is the calculated light extinction coefficient; $k_{w}$ is the light extinction coefficient for clear water $\left(\mathrm{m}^{-1}\right) ; C_{l}$ is the concentration of phytoplankton ( $\mu \mathrm{g} \mathrm{Chla} \mathrm{L}^{-1}$ ), and $k_{1}$ is the specific extinction coefficient for phytoplankton $\left(\mathrm{m}^{-1} *\left[\mu \mathrm{g} \text { Chla L }{ }^{-1}\right]^{-1}\right)$. Literature values of $k_{1}$ for different phytoplankton groups range from 0.01 to 0.03 (Hamilton and Schladow 1997, Reynolds 2006); for this study a middle value of $0.015 \mathrm{~m}^{-1} *\left[\mu \mathrm{g} \mathrm{Chla}^{-1}\right]^{-1}$ was adopted.

The TP required to support the growth of phytoplankton cells in the system was estimated from the Chla concentration obtained as the sum of the flushed and unflushed phytoplankton cells predicted by the phytoplankton growth and dilution model. Although several Chla and TP relationships have been identified, the equation (Dillon and Rigler 1974):

$$
\begin{aligned}
& \log 10\left[\mathrm{Chla}\left(\mathrm{mg} \mathrm{m}^{-3}\right)\right]=1.583 \log 10\left[\mathrm{TP}\left(\mathrm{mg} \mathrm{m}^{-3}\right)\right]-1.134 \\
& \left(\mathrm{r}^{2}=0.975\right) \quad(\text { Eqn. } 6)
\end{aligned}
$$

was adopted for estimating TP from the Chla concentration in this study because it was obtained using a variety of ecosystems and fit the data better than other available equations. Phytoplankton growth at different nutrient conditions was then assessed via bioassay experiments (Appendix 1). Because of the short residence times in the ponds, and to consider different growth rates $\left(r_{i}\right)$ and dilution or flushing rates $\left(D_{i}\right)$, phytoplankton cell concentration of a model population was calculated as:

$$
C_{t_{i}}\left(r_{i}, D_{i}, T P\right)=C_{t_{i-1}} * e^{r_{i} *\left(t_{i}-t_{i-1}\right)}-C_{t_{i-1}} * D_{i}
$$

where $C_{t i}$ is the phytoplankton concentration in cells $/ \mathrm{mL}$ at time $t_{i}$. The cell development was calculated for a 20-day period with a time step of 1 day. The growth rates were varied within different model runs from 0.1 to $1.2 \mathrm{~d}^{-1}$ spanning a wide range of phytoplankton species. Growth rates higher than $1.2 \mathrm{~d}^{-1}$ were observed in laboratory culture under continuous light and maximum resource (TP) availability, but these rates are unlikely to occur in the ponds based on the known variation in current conditions. Dilution rates (Table 1) were chosen to represent a range of flows from a dilution rate of $250 \%$ (approximately representing current conditions) down to a potential future dilution rate of $75 \%$ under reduced inflows. Phytoplankton biomass in Chla $\left(\mathrm{mg} \mathrm{m}^{-3}\right)$ was calculated also on the basis of the TP concentration available in Ewens Ponds if released from the sediments.

Two different initial conditions were considered: an inoculum of 100 cells $\mathrm{mL}^{-1}$ and an inoculum of 1000 cells $\mathrm{mL}^{-1}$. These correspond to Chla concentrations of nondiatomaceous phytoplankton of 0.0135 and $0.135 \mu \mathrm{g}$ Chla $\mathrm{L}^{-1}$, respectively (Reynolds 2006). Cell concentrations obtained from the model not flushed via the outflow were converted to Chla concentrations and used to estimate light attenuation for macrophytes. An estimated chlorophyll content of $1.37 \mu \mathrm{g}$ Chla cell $^{-1}$ was adopted considering cell volumes of approximately $30 \mu \mathrm{m}^{3}$ representing green algae approximately the size of Ankistrodesmus as observed 
Table 1. Dilution rates, residence times, and flows adopted in the model.

\begin{tabular}{lcc}
\hline \hline Dilution rate & Residence time $(\mathrm{d})$ & Flow $\left(\mathrm{m}^{3} \mathrm{~s}^{-1}\right)$ \\
\hline $75 \%$ & 1.33 & 0.2431 \\
$100 \%$ & 1.00 & 0.3241 \\
$170 \%$ & 0.59 & 0.5509 \\
$200 \%$ & 0.50 & 0.6481 \\
$250 \%$ & 0.40 & 0.8102 \\
\hline
\end{tabular}

in Myponga reservoir (South Australia) and a cell ratio C:Chla of 50:1 (Reynolds 2006).

\section{RESULTS}

\section{Water and nutrient budgets}

Outflow was measured at $0.733 \mathrm{~m}^{3} \mathrm{~s}^{-1}, 0.729 \mathrm{~m}^{3} \mathrm{~s}^{-1}$, and $1.052 \mathrm{~m}^{3}$ $\mathrm{s}^{-1}$ at the outlets of ponds 1,2 , and 3, respectively. Approximately $70 \%$ of total inflow entered from groundwater into pond $1,0 \%$ into pond 2 , and $30 \%$ into pond 3 (Table 2). The retention time for the whole system is approximately 0.48 days (residence times of 0.44 in pond 1 ), so all the water in the system is replaced in less than 12 hours.

Over the length of the study period, total outflows from the ponds was approximately $81,000-133,000 \mathrm{~m}^{3} \mathrm{~d}^{-1}\left(0.9-1.5 \mathrm{~m}^{3} \mathrm{~s}^{-1}\right)$, and measured outflows varied less than $0.04 \%$ from estimated groundwater inflows entering the ponds in May 2015 (Table 2). Water level at the outlet of pond 3 was almost constant over the measured period from May 2014 to January 2015: a decrease of about $0.1 \mathrm{~m}$ was observed from May to September followed by a similar increase from September to December. This was consistent with total outflow measurements (i.e., from the StarFlow flow meter at the outlet of pond 3) that detected a higher flow in December than in September. Specific conductivity was not consistent between ponds. Between 15 August and the beginning of December, the specific conductivity recorded in ponds 1 and 2 was relatively consistent at approximately $750 \mu \mathrm{S} / \mathrm{cm}$ in both ponds. Specific conductivity over the same period was also consistent at pond 3 at approximately $800 \mu \mathrm{S} / \mathrm{cm}$. Therefore, the ratio of the salinity between pond 3 outflow and pond 1 was considered indicative of the ratio between the relative flow entering pond 1 and pond 3, and this ratio was used both for the water budget and nutrient budget calculations.

Temperature profiles, thermistor data, and oxygen profiles showed the water column in the ponds was well mixed and well oxygenated throughout the year. Temperature was almost constant at about $15^{\circ} \mathrm{C}$ and no temperature difference was observed between the three ponds. The average concentrations of TP and TN in Ewens Ponds during the study period were 0.022 $\mathrm{mg} \mathrm{L}^{-1}$ and $5.8 \mathrm{mg} \mathrm{L}^{-1}$, respectively (Fig. 2, Appendix 2). The TN concentration was extremely high and well above the guidelines of $1 \mathrm{mg} \mathrm{L}^{-1}$ for inland water bodies of South Australia. In contrast, TP was well below the guidelines of $0.1 \mathrm{mg} \mathrm{L}^{-1}$ (Australian and New Zealand Environment and Conservation Council 2000). The stoichiometry of N:P suggested the ponds were P limited. The nutrient budget suggested that the input of nutrients from the sediment was close to zero, and nutrients were quickly flushed from the system because of low retention rates (Table 2).
Fig. 2. Nutrient concentrations: (A) Average total phosphorous and (B) total nitrogen concentration and standard error deviation ( $\pm \mathrm{SE}$ ) of 6 to 9 replicate samples in the water column of the ponds, individual groundwater samples from the ponds (measured in May 2014 and January 2015 only), and average concentration of water sampled at bores MAC045 and MAC094 in the unconfined aquifer (Fig. 1). Lines between points do not infer connection between the data.

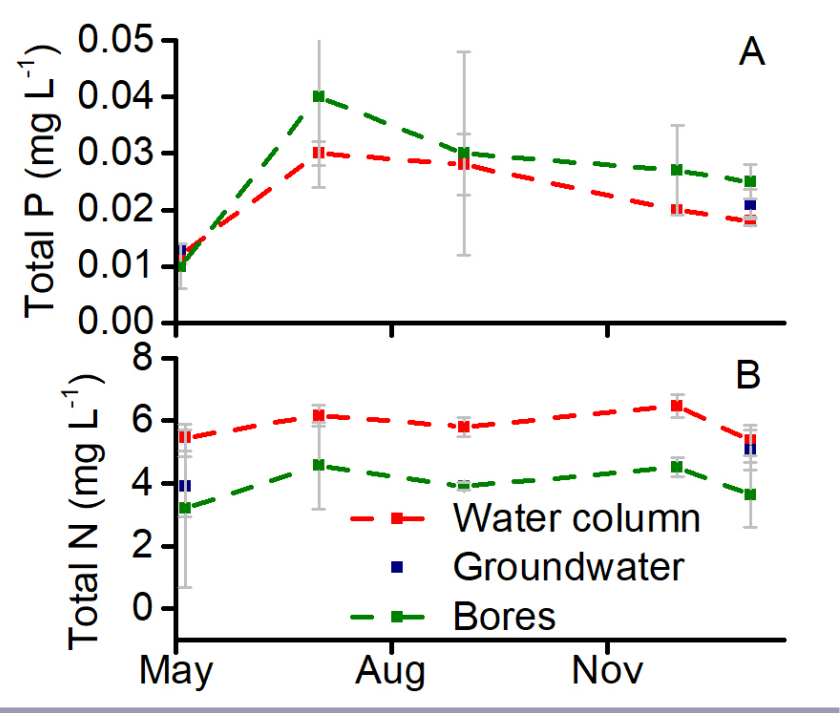

Total phosphorus concentrations at bores MAC094 and MAC045 (the two bores sampled during each field investigation) was generally higher than that of the ponds, whereas total nitrogen concentrations were always lower than in the ponds (Fig. 2). No correlation was found between nutrient concentrations at bores MAC094 and MAC045 and at the ponds. The nutrient concentrations in groundwater inflow to the ponds generally fell in between the bore and pond concentrations, with the exception of the total phosphorus concentration in May 2014. In comparison to these two bores, the three additional bores in the unconfined aquifer sampled in September 2014 (Fig. 1) had higher total nitrogen concentrations of $6.4-14.7 \mathrm{mg} \mathrm{L}^{-1}$ and similar or higher total phosphorus concentrations of 0.03-0.06 $\mathrm{mg} \mathrm{L}^{-1}$.

\section{Field and laboratory experiments}

\section{Sediment fluxes}

The average sediment dissolved oxygen demand ( $24 \mathrm{~h}$ ) was 415 $\mathrm{mg} \mathrm{O}_{2} \mathrm{~m}^{-2} \mathrm{~d}^{-1}$ with a standard deviation of $215 \mathrm{mg} \mathrm{O}_{2} \mathrm{~m}^{-2} \mathrm{~d}^{-1}$ and high variability between samples. No statistical difference $(p>$ 0.05 ) was identified between oxygen demand calculated at different ponds or at different depths. Differences between initial and final concentrations for TN were not significant $\chi^{2}(2)=3.769$, $p=0.052$, therefore the flux for $\mathrm{TN}$ was considered negligible. Nitrite flux was negligible (averaged $<1 \mathrm{mg} \mathrm{m}^{-2} \mathrm{~d}^{-1}$ ). Nitrate fluxes were negative indicating that nitrate was reduced to ammonium. A release of TP was observed from the sediment during anoxic conditions at a rate of $2.4 \mathrm{mg} \mathrm{P} \mathrm{m} \mathrm{d}^{-1}$. For TP and orthophosphate, the fluxes were not significantly different between sites or by depth $(p=0.135)$ varying between 1 to $8 \mathrm{mg}$ $\mathrm{P} \mathrm{m}^{-2} \mathrm{~d}^{-1}$ depth (Fig. 3). 
Table 2. Ewens Ponds water balance and nutrient balance as calculated from equations 2 and 3 . Groundwater inflow from pond 2 was negligible and is therefore not shown.

\begin{tabular}{|c|c|c|c|c|c|}
\hline & \multirow[t]{2}{*}{$\begin{array}{l}\text { Total Outflow } \\
\left(\mathrm{m}^{3} \mathrm{~d}^{-1}\right) \\
\end{array}$} & \multicolumn{2}{|c|}{$\begin{array}{l}\text { Water balance } \\
\text { Groundwater Inflow } \\
\left(\mathrm{m}^{3} \mathrm{~d}^{-1}\right)\end{array}$} & \multicolumn{2}{|c|}{$\begin{array}{l}\text { Total Groundwater Inflow } \\
\qquad\left(\mathrm{m}^{3} \mathrm{~d}^{-1}\right)\end{array}$} \\
\hline & & Pond 1 & Pond 3 & \multirow[b]{2}{*}{90886} & \\
\hline May 2014 & 90893 & 63325 & 27561 & & \\
\hline July 2014 & 115776 & 81038 & 34731 & \multicolumn{2}{|c|}{115768} \\
\hline Sept 2014 & 80819 & 56594 & 24250 & \multicolumn{2}{|c|}{80844} \\
\hline Dec 2014 & 133056 & 92464 & 40613 & \multicolumn{2}{|c|}{133077} \\
\hline \multirow[t]{5}{*}{ Jan 2015} & 103680 & 72589 & 31108 & 10369 & \\
\hline & & \multirow{2}{*}{\multicolumn{2}{|c|}{ Nutrient balance }} & & \\
\hline & \multicolumn{3}{|l|}{$\mathrm{TP}\left(\mathrm{mg} \mathrm{d}^{-1}\right)$} & & \\
\hline & Total Outlet & \multicolumn{2}{|c|}{ Groundwater Inlet } & Total Groundwater Inlet & Net Budget \\
\hline & & Pond 1 & Pond 3 & & \\
\hline May 2014 & 1.109 & 0.773 & 0.336 & 1.109 & $-8.5 \mathrm{E}-07$ \\
\hline July 2014 & 3.531 & 2.472 & 1.059 & 3.531 & 0 \\
\hline Sept 2014 & 2.272 & 1.591 & 0.682 & 2.273 & 0.0007 \\
\hline Dec 2014 & 2.661 & 1.849 & 0.812 & 2.662 & 0.0004 \\
\hline \multirow[t]{4}{*}{ Jan 2015} & 1.866 & 1.307 & 0.560 & 1.867 & 0.0003 \\
\hline & \multicolumn{5}{|l|}{$\mathrm{TN}\left(\mathrm{mg} \mathrm{d}^{-1}\right)$} \\
\hline & Total Outlet & \multicolumn{2}{|c|}{ Groundwater Inlet } & Total Groundwater Inlet & Net Budget \\
\hline & & Pond 1 & Pond 3 & & \\
\hline May 2014 & 496.0 & 345.6 & 150.4 & 495.9 & -0.040 \\
\hline July 2014 & 714.8 & 500.3 & 214.4 & 714.8 & -0.047 \\
\hline Sept 2014 & 468.9 & 328.3 & 140.7 & 469.0 & 0.147 \\
\hline Dec 2014 & 860.4 & 597.9 & 262.6 & 860.5 & 0.138 \\
\hline Jan 2015 & 556.9 & 389.9 & 167.1 & 557.0 & 0.088 \\
\hline
\end{tabular}

Fig. 3. Total phosphorus fluxes estimated for 13 cores collected in pond 1 , pond 2 , and pond 3 at depths indicated.

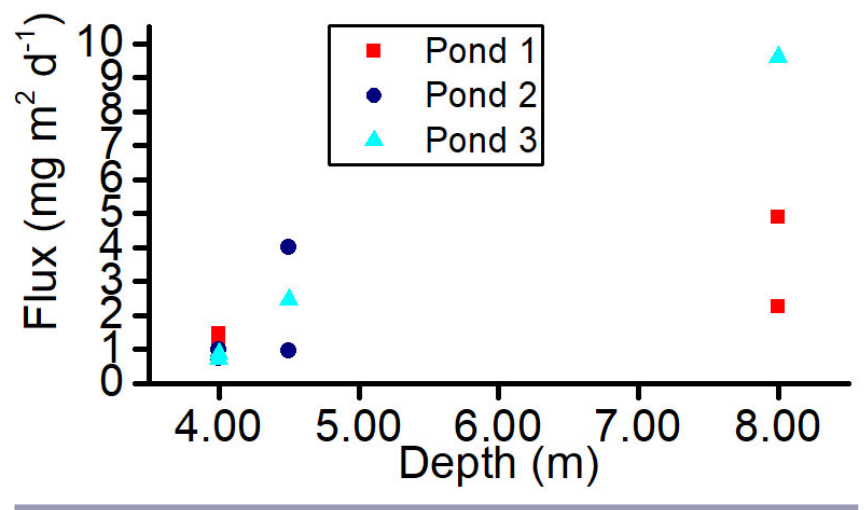

Macrophyte photosynthesis in response to light intensity

Net primary productivity ranged from values close to zero at light lower than $25 \mu \mathrm{mol} \mathrm{m}^{-2} \mathrm{~s}^{-1}$, to approximately $0.1 \mathrm{mg} \mathrm{O}_{2} \mathrm{~g}^{-1} \mathrm{dw} \mathrm{h}^{-1}$ at high light intensity of about $340 \mu \mathrm{mol} \mathrm{m} \mathrm{m}^{-2} \mathrm{~s}^{-1^{2}}$ (Fig. 4). Productivity rates showed a large variation between domes and at different light conditions. Productivity steeply increased with light up to about $120 \mu \mathrm{mol} \mathrm{m} \mathrm{m}^{-2} \mathrm{~s}^{-1}$ where it was close to $0.07 \mathrm{mg}$ $\mathrm{O}_{2} \mathrm{~g}^{-1} \mathrm{dw} \mathrm{h}$. At high light, a higher variability in productivity was observed between domes. Photosynthetic rates suggest that macrophyte development would be compromised at light values lower than approximately $80 \mu \mathrm{mol} \mathrm{m} \mathrm{m}^{-2} \mathrm{~s}^{-1}$.
Fig. 4. Hourly net primary productivity for macrophytes at different light exposures determined through the submersed domes experiment.

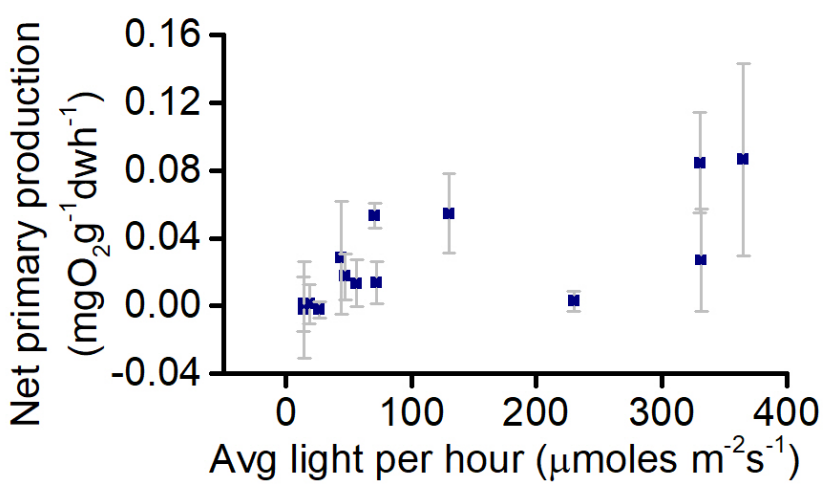

Groundwater dating

The apparent recharge years from CFC-12 results fell within a relatively narrow range of years from 1975 to 1988 for all samples (Table 3). No trend in age difference was apparent between the ponds. The age of the groundwater at the bore closest to the ponds (MAC 094) was about 10 years younger than the groundwater discharge into the ponds, suggesting that there was not a single and direct flow of this aquifer to the ponds. 
Table 3. Groundwater dating results: CFC-12. The endpoints of the range of apparent recharge estimates are bold.

\begin{tabular}{lccc}
\hline \hline Site & $\begin{array}{c}\text { Atmospheric Partial } \\
\text { Pressure (pptv) }\end{array}$ & Error \pm & $\begin{array}{c}\text { Apparent } \\
\text { recharge year }\end{array}$ \\
\hline Inflow Pond 1 & 422 & 37 & 1987.5 \\
Inflow Pond 2 & 379 & 31 & 1985.5 \\
& 421 & 49 & 1987.5 \\
Inflow Pond 3 & 400 & 46 & 1986.5 \\
& 332 & 38 & 1982.5 \\
Outflow Pond 1 & 192 & 23 & $\mathbf{1 9 7 5 . 0}$ \\
& 396 & 45 & 1986.0 \\
Outflow Pond 2 & 414 & 35 & 1987.0 \\
Outflow Pond 3 & 391 & 32 & 1986.0 \\
MAC045 (Bore) & 405 & 30 & 1986.5 \\
MAC094 (Bore) & 430 & 39 & $\mathbf{1 9 8 8 . 0}$ \\
\hline
\end{tabular}

\section{Phytoplankton growth and dilution modeling}

Modeling showed that the chlorophyll-a concentrations that allowed the system to maintain the present light conditions and to decrease the maximum depth of colonization for macrophytes by $1 \mathrm{~m}$ were $0.5 \mu \mathrm{g}$ and $5.5 \mu \mathrm{g} \mathrm{Chla}^{-1}$, respectively. It was estimated that the system could reach these Chla levels if the TP in the water column in the ponds was at least 0.004 and $0.02 \mathrm{mg}$ $\mathrm{L}^{-1}$, respectively, corresponding to particular combinations of dilution rates and phytoplankton growth rates ( Fig. 5, Table 4). Modeled pelagic phytoplankton growth did not occur below growth rates of $0.6-0.8 \mathrm{~d}^{-1}$ under any of the tested conditions.

Fig. 5. Modeling results: phytoplankton growth as a function of groundwater inflow through the ponds. Dashed lines indicate conditions for which macrophyte domination was maintained, whereas the solid lines indicate that a switch to phytoplankton would be observed.

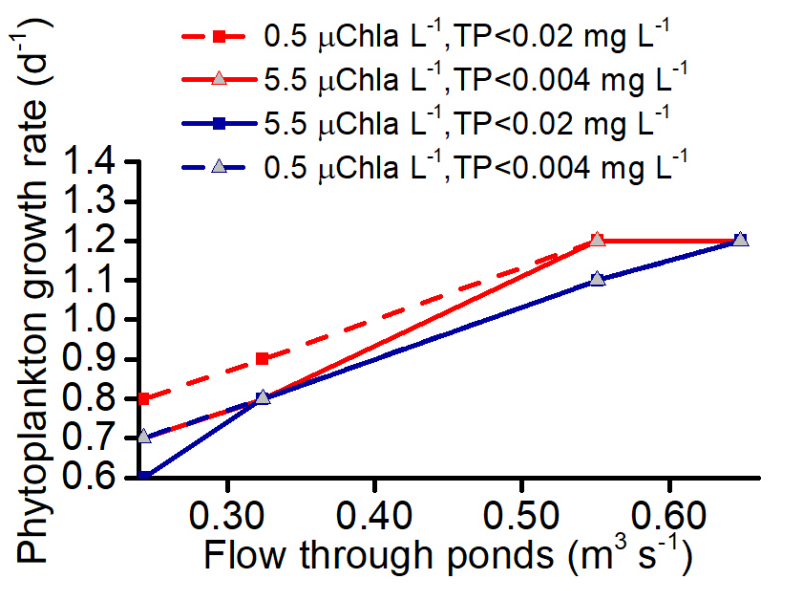

Assuming a reduced dilution rate of $170 \%$, that all the phosphorus released was available for uptake and algal growth, and phytoplankton growth under stratified-anoxic conditions (Equation 6), the $\mathrm{P}$ released would generate an increase in the algal biomass of about $13 \mu \mathrm{g} \mathrm{Chla}^{-1}$ in 20 days. Following Lambert-Beer law, this would result in a decrease of light
Table 4. Model results. Phytoplankton biomass required to create conditions satisfying modeled macrophyte light requirement scenarios. Limit 1 is sufficient to maintain present light conditions wheras Limit 2 would decrease macrophyte depth of colonization by $1 \mathrm{~m}$. TP is total phosphorus and $\mathrm{r}$ is phytoplankton growth rate (day-1).

\begin{tabular}{|c|c|c|}
\hline & Limit 1 & Limit 2 \\
\hline Light & $73 \mathrm{umol} \mathrm{m}^{-2} \mathrm{~s}^{-1}$ & $48 \mathrm{umol} \mathrm{m}^{-2} \mathrm{~s}^{-1}$ \\
\hline Phytoplankton biomass & $0.5 \mu \mathrm{Chla} \mathrm{L}^{-1}$ & $5.5 \mu \mathrm{Chla} \mathrm{L}^{-1}$ \\
\hline \multicolumn{3}{|l|}{ Conditions } \\
\hline \multicolumn{3}{|c|}{ Inoculum 100 cells $/ \mathrm{mL}\left(0.0135 \mu \mathrm{Chla} \mathrm{L}^{-1}\right)$} \\
\hline & $\mathrm{TP}<0.004 \mathrm{mg} \mathrm{L}^{-1}$ & $\mathrm{TP}<0.02 \mathrm{mg} \mathrm{L}^{-1}$ \\
\hline \multicolumn{3}{|l|}{ Residence time (day) } \\
\hline 1.33 & $r<0.7$ & $r<0.8$ \\
\hline 1.00 & $r<0.8$ & $r<0.9$ \\
\hline 0.59 & $r<1.2$ & $r<1.2$ \\
\hline 0.50 & $r<1.2$ & - \\
\hline 0.40 & - & - \\
\hline \multicolumn{3}{|c|}{ Inoculum 1000 cells/mL $\left(0.135 \mu \mathrm{Chla} \mathrm{L}^{-1}\right)$} \\
\hline & $\mathrm{TP}<0.004 \mathrm{mg} \mathrm{L}^{-1}$ & $\mathrm{TP}<0.02 \mathrm{mg} \mathrm{L}^{-1}$ \\
\hline \multicolumn{3}{|l|}{ Residence time (day) } \\
\hline 1.33 & $r<0.6$ & $r<0.7$ \\
\hline 1.00 & $r<0.8$ & $r<0.8$ \\
\hline 0.59 & $r<1.1$ & $r<1.1$ \\
\hline 0.50 & $r<1.2$ & $r<1.2$ \\
\hline 0.40 & - & - \\
\hline
\end{tabular}

availability for macrophyte growth of about $50 \%$. This is estimated to be the worst-case scenario.

\section{DISCUSSION}

The clear waters of Ewens Ponds are a key component of its ecological character and the outstanding underwater visibility means it is a coveted diving experience. Maintaining the water clarity relies upon controlling phytoplankton growth by controlling nutrient inputs and/or ensuring flows are sufficiently high that phytoplankton communities are flushed out and cannot establish in the ponds. The water and nutrient balances showed that the main factors controlling the risk of regime shift in Ewens Ponds are phosphorus availability and flow rate. The average influx calculated during the monitoring period was approximately $2.3 \mathrm{mg} \mathrm{d}^{-1}$ for TP and $619 \mathrm{mg} \mathrm{d}^{-1}$ for TN. The estimated nutrient budget suggested that most of these inputs were coming from groundwater and were flushed out of the system with limited accumulation in the sediments or assimilation into biomass.

Field and laboratory experiments identified that if flow were reduced, both phosphorus and nitrogen could play an important role in stimulating phytoplankton growth. With reduced flow, sediment could become anoxic, resulting in a flux of TP into the water column, thereby enhancing phosphorus availability and increasing algal growth. There has been a marked reduction in flow from the 1980s to now; $2.28 \mathrm{~m}^{3} \mathrm{~s}^{-1}$ observed in 1979 (Grandfield and Ashman 1984) to only $0.9-1.5 \mathrm{~m}^{3} \mathrm{~s}^{-1}$ in the current study. This flow reduction is attributed to an increasing irrigation demand on the water resources that supply inflow to the ponds. This is a widespread issue and has also been cited as one of the main reasons for loss of ecological functions in arid and semiarid regions in USA and Mexico (Minckley et al. 2013). 
The age of the groundwater entering Ewens Ponds was in line with the results of our nutrient analysis and also with previous results that estimated water age at approximately 23 years, using analogous techniques (Wood 2011). Using this groundwater age, we can estimate future trends in $\mathrm{N}$ and $\mathrm{P}$ concentrations by examining fertilizer use in Australia since the time that the groundwater entered the system (Fig. 6). Both N and P use showed a rise from 1991 to 1998 (Fertilizer Industry Federation of Australia 2011) and then decreased slightly in the $21^{\text {st }}$ century (FAO 2014, World Bank 2014). Therefore, higher levels of nutrients are expected to enter Ewens Ponds via groundwater inflows in the future, with peak nutrient loads occurring in the years 2024-2037.

Fig. 6. Trends in fertilizer use (nitrogen and phosphorus) in Australia (FAO 2014, World Bank 2014) from 1962 through 2012. Vertical dashed lines indicate the period during which groundwaters entering Ewens Ponds recharged the aquifer, based on the results of groundwater dating in this study.

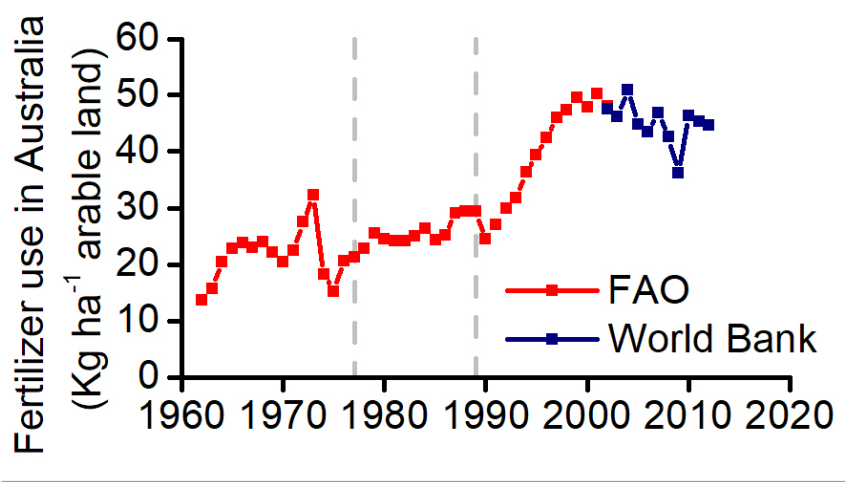

The modeling aim was to identify a nutrient threshold that would limit phytoplankton growth and maintain water clarity satisfying the light requirements for macrophyte development. The development of phytoplankton communities in small lakes such as Ewens Ponds is a function of nutrient availability, light availability, and washout of the population by flow (Nõges et al. 1998, Phillips et al. 2008). Following the paradigm proposed by Davis et al. (2010) to classify shallow lentic ecosystems, the initial development of benthic mats on the bottom of the ponds is an indication of a change from a clear, plant dominated ecosystem a to clear, benthic mat dominated system.

A previous study identified the maximum depth of colonization for the five most common species of macrophytes in Ewens Ponds as $1.5 \mathrm{~m}$ for Triglochin procera; $4 \mathrm{~m}$ for Hydrocotyle verticillata, Ranunculus inundates, and Triglochin striata; and $5 \mathrm{~m}$ for Lilaeopsis polyantha (Grandfield and Ashman 1984). Therefore, a $1 \mathrm{~m}$ shift in available light would represent a significant (20-66\%) loss of habitat for these macrophytes. The modeling results showed that this shift in light availability could happen at levels of TP within the range already observed during this study (i.e., roughly $0.2 \mathrm{mg} \mathrm{L}^{-1}$ ) in conjunction with lower groundwater inflow to the ponds. This modeling result again supports the finding that the main factor controlling phytoplankton biomass at present is flushing. We identified a lower flow threshold required to prevent the shift from plant domination to benthic mats (i.e., inflows < $\left.0.55 \mathrm{~m}^{3} \mathrm{~s}^{-1}\right)$, but modeling also predicted that a reduction in flow of only $20 \%$ compared to current conditions could be sufficient to allow phytoplankton dominance if the concentration of phytoplankton cells present in the ponds increases above current levels (i.e., we used current levels of phytoplankton cell concentration as our initial concentration for the modeling).

These results again highlight interactions between multiple stressors in preserving ecosystem health. Since the initial studies conducted in Ewens Ponds in the 1970s, groundwater inflows have decreased by as much as $1.4 \mathrm{~m}^{3} \mathrm{~s}^{-1}$ (i.e., they are now typically only half of the historical flow); a much greater decrease than the $0.25 \mathrm{~m}^{3} \mathrm{~s}^{-1}$ reduction estimated for a regime shift given low existing phytoplankton levels. How much more flow will be lost as the use of center pivot irrigation systems increases in the region is unknown, especially given the karst hydrology of the region. Future stressor interaction in these wetlands will also depend on the physiological characteristics and behavior of the pelagic algae developing in the ponds (Carey et al. 2012, Rigosi et al. 2014), which was outside the scope of the current study. Therefore, the likelihood of a regime shift in the ponds remains hard to predict, despite the clear thresholds identified in this study.

In summary, the results of this study clearly show a balance between flows and nutrient loads. Neither of these stressors is sufficient to shift the wetland ecosystem from macrophyte to phytoplankton domination on its own, but experiments and modeling suggested the combination of lower flows and increased phosphorus (in particular) could have a marked impact on the colonization depth of macrophyte communities and allow increased phytoplankton growth. Although management of nutrient loads is important, these wetlands are groundwater driven, and groundwater dating showed that it will be difficult to reduce nutrient loads into the ponds for many years. Therefore, it is clear from this study that preservation of Ewens Ponds will require the management of groundwater withdrawals in the surrounding region, and thus a societal struggle between agricultural and ecosystem (and tourism) importance. Despite the development of several brochures and a website detailing the concern over wetland health and observations of algal blooms by divers, limits on nutrient application or groundwater use in the region have not followed. This is perhaps due to a lack of quantifiable connections between groundwater withdrawals and inflow to the ponds. Developing the link between these two would require more information on changes in inflow to the ponds over time in conjunction with overall groundwater withdrawals from the shallow aquifer over the same time period. Therefore, continued monitoring of flow through the ponds should be considered. A greater understanding of the karst geology in this region would also help to manage sustainability of groundwater withdrawals. The limits on combined nutrient levels and flows elucidated through this study could then be employed to help prevent changes in the ecosystem.

Stressors such as increasing nutrients and decreasing water flow, due to climate or enhanced groundwater extraction, are frequently observed in shallow freshwater systems globally (Lemly et al. 2000, Brinson and Malvarez 2002). In other regions of the world, in particular in arid countries strongly affected by a warming climate, the importance of wetland conservation is even more evident, showing that loss of freshwater wetlands means not just a loss in biodiversity, but also a loss of economic, social, 
functional, and cultural values for the people living in the surrounding areas (Shuyt 2005). Improving the understanding of how multiple stressors interact and calculating thresholds to avoid a regime shift through modeling exercises, as achieved with the present study, is fundamental to identifying appropriate management strategies for long-term conservation of freshwater ecosystems.

\section{CONCLUSIONS}

As is the case for wetlands around the world, the hydrology of the wetlands that once characterized much of the Southeast of South Australia have been extensively modified by a combination of drainage schemes, land clearance, and water extraction since European settlement in the 1860s. The results of this study indicate that conservation planning for these wetlands must focus on maintaining high flow, determining recharge areas, forecasting water demands, and reducing phosphorus inputs. Given the observed lag time between nutrient use in the watershed and groundwater entering the ponds, combined with literature values of nutrient use over time, it is unlikely that phosphorus input can be reduced in the short-term, further highlighting the need to preserve flow rates into the ponds.

Flow regimes are an important but neglected proxy for ecosystem stability. Through climate change, it is likely that alteration of hydrology will affect wetlands profoundly and have different consequences depending on the type of wetland (Burkett and Kussler 2000). The ecosystem implications of these alterations will also vary; in freshwater wetlands, climate change will add additional stressors that will favor more efficient colonizers (Erwin 2009). Under these conditions, even maintaining current (lowered, as compared to historic) flows may not be sufficient for conservation. Therefore, understanding ecosystem limits will be crucial for conserving these threatened systems.

Responses to this article can be read online at: http://www.ecologyandsociety.org/issues/responses. php/11437

\section{Acknowledgments:}

The project that initiated this manuscript was financially supported by The Goyder Institute for Water Research, Project E. 2.7. Author Shanafield was supported by funding from the Australian Research Council under grant DE150100302. The authors thank Mark de Jong, South Eastern Water Conservation and Drainage Board (SEWCDB), Claire Harding and Cameron Wood, Department of Environment Water and Natural Resources (DEWNR), Peter Cook, Flinders University, Ross Anderson, DEWNR, and Sean Connell, The University of Adelaide (UoA) for their helpful contribution discussing several scientific aspects of the project and Nick White, Druk Verschure, and Jake Manster for their supporting field work. Peter Goonan, EPA SA Government, and Kane Aldridge, UoA, helped gather data on nutrients in the South East wetlands. We thank DEWNR for facilitating the access and supporting research conducted at Ewens Ponds. Maria Marklund (UoA), Sam England, and several anonymous reviewers provided valuable comments on the manuscript. The authors declare that they have no conflict of interest.

\section{LITERATURE CITED}

American Public Health Association (APHA). 2005. Standard methods for the examination of water and wastewater. 21st edition. American Public Health Association, American Water Works Association, Water Environment Federation, Washington, D.C., USA.

Australian and New Zealand Environment and Conservation Council. 2000. Australian and New Zealand guidelines for fresh and marine water quality. Australian and New Zealand Environment and Conservation Council, Canberra, Australia. [online] URL: https://www.waterquality.gov.au/anz-guidelines/ resources/previous-guidelines/anzecc-armcanz-2000

Blann, K. L., J. L. Anderson, G. R. Sands, and B. Vondracek. 2009. Effects of agricultural drainage on aquatic ecosystems: a review. Critical Reviews in Environmental Science and Technology 39(11):909-1001. https://doi.org/10.1080/10643380801977966

Brinson, M. M., and A. I. Malvárez. 2002. Temperate freshwater wetlands: types, status, and threats. Environmental Conservation 29(02):115-133. https://doi.org/10.1017/S0376892902000085

Burkett, V., and J. Kusler. 2000. Climate change: potential impacts and interactions in wetlands of the United States. JAWRA Journal of the American Water Resources Association 36(2):313-320. https://doi.org/10.1111/j.1752-1688.2000.tb04270.x

Busemberg, E., and L. N. Plummer. 1992. Use of chlorofluorocarbons $\left(\mathrm{CCl}_{3} \mathrm{~F}\right.$ and $\left.\mathrm{CCl}_{2} \mathrm{~F}_{2}\right)$ as hydrologic tracers and age-dating tools: the alluvium and terrace system of Central Oklahoma. Water Resources Research 28:2257-2283. https://doi. org/10.1029/92WR01263

Carey, C. C., B. W. Ibelings, E. P. Hoffmann, D. P. Hamilton, and J. D. Brookes. 2012. Eco-physiological adaptations that favour freshwater cyanobacteria in a changing climate. Water Research 46:1394-1407. https://doi.org/10.1016/j.watres.2011.12.016

Carmody, G. 2006. Save Ewens ponds! Australia New Guinea Fishes Association (ANGFA), Victoria, Australia. [online] URL: http://citeseerx.ist.psu.edu/viewdoc/download;jsessionid= BF0E41CAFD8FF1F0439B1ECA843EB664?doi=10.1.1.732.6559\&rep= rep1\&type $=$ pdf

Carpenter, S. R., and K. L. Cottingham. 1997. Resilience and restoration of lakes. Conservation Ecology 1(1):2. https://doi. org/10.5751/ES-00020-010102

Cook, P. G., D. K. Solomon, L. N. Plummer, E. Busemberg, and S. L. Schiff. 1995. Chlorofluorocarbons as tracers of groundwater transport processes in a shallow, silty sand aquifer. Water Resources Research 31:425-434. https://doi.org/10.1029/94WR02528

Danielopol, D. L., C. Griebler, A. Gunatilaka, and J. Notenboom. 2003. Present state and future prospects for groundwater ecosystems. Environmental Conservation 30(2):104-130. https:// doi.org/10.1017/S0376892903000109

Davidson, N. C. 2014. How much wetland has the world lost? Long-term and recent trends in global wetland area. Marine and Freshwater Research 65(10):934-941. https://doi.org/10.1071/ MF14173 
Davis, J., L. Sim, and J. Chambers. 2010. Multiple stressors and regime shifts in shallow aquatic ecosystems in antipodean landscapes. Freshwater Biology 55:5-18. https://doi.org/10.1111/ j.1365-2427.2009.02376.x

Dillon, P. J., and F. H. Rigler. 1974. The phosphorous-chlorophyll relationship in lakes. Limnology and Oceanography 19:767-773. https://doi.org/10.4319/10.1974.19.5.0767

Elliott, J. A. 2010. The seasonal sensitivity of cyanobacteria and other phytoplankton to changes in flushing rate and water temperature. Global Change Biology 16:864-876. https://doi. org/10.1111/j.1365-2486.2009.01998.x

Erwin, K. L. 2009. Wetlands and global climate change: the role of wetland restoration in a changing world. Wetlands Ecology and Management 17(1):71. https://doi.org/10.1007/s11273-008-9119-1

Fertilizer Industry Federation of Australia. 2011. Fertilizer industry environment, report 2011. Fertilizer Industry Federation of Australia, Canberra, Australia.

Food and Agriculture Organization of the United Nations (FAO). 2014. FAOSTAT database. Food and Agriculture Organization of the United Nations, Rome, Italy. [online] URL: http://www. fao.org/faostat/en/\#home

Grandfield, L., and G. Ashman. 1984. Ewens Ponds management plan. Department of Lands, South East Region, Mt. Gambier, Australia.

Gunn, J. M., E. Snucins, N. D. Yan, and M. T. Arts. 2001. Use of water clarity to monitor the effects of climate change and other stressors on oligotrophic lakes. Environmental Monitoring and Assessment 67:69-88. https://doi.org/10.1023/A:1006435721636

Hamilton, D. P., and S. G. Schladow. 1997. Prediction of water quality in lakes and reservoirs. Part I-Model description. Ecological Modelling 96:91-110. https://doi.org/10.1016/S0304-3800 (96)00062-2

Hipsey, M. R., D. P. Hamilton, P. C. Hanson, C. C. Carey, J. Z. Coletti, J. S. Read, B. W. Ibelings, F. Valesini, and J. D. Brookes. 2015. Predicting the resilience and recovery of aquatic systems: a framework for model evolution within environmental observatories. Water Resources Research 51:7023-7043. https:// doi.org/10.1002/2015WR017175

Ibelings, B. W., R. Portielje, E. H. R. R. Lammens, R. Noordhuis, M. S. van den Berg, W. Joosse, and M. L. Meijer. 2007. Resilience of alternative stable states during the recovery of shallow lakes from eutrophication: Lake Veluwe as a case study. Ecosystems 10:4-16. https://doi.org/10.1007/s10021-006-9009-4

Kirk, J. T. O. 2011. Light and photosynthesis in aquatic ecosystems. Cambridge University Press, Cambridge, UK.

Lemly, A. D., R. T. Kingsford, and J. R. Thompson. 2000. Irrigated agriculture and wildlife conservation: conflict on a global scale. Environmental Management 25(5):485-512. https:// doi.org/10.1007/s002679910039

Minckley, T. A., D. S. Turner, and S. R. Weinstein. 2013. The relevance of wetland conservation in arid regions: a reexamination of vanishing communities in the American Southwest. Journal of Arid Environments 88:213-221. https://doi. org/10.1016/j.jaridenv.2012.09.001
Mitsch, W. J., and J. G. Gosselink. 2000. The value of wetlands: importance of scale and landscape setting. Ecological Economics 35(1):25-33. https://doi.org/10.1016/S0921-8009(00)00165-8

Mustafa, S., S. Slater, and S. Barnett. 2012. Preliminary investigation of seawater intrusion into a freshwater coastal aquifer. Technical Report DEWNR 2012/01. Lower Southeast Department of Environment, Water and Natural Resources, Adelaide, South Australia, Australia. [online] URL: https://www. waterconnect.sa.gov.au/Content/Publications/DEW/ DEWNR TR 2012 01.pdf

National Parks and Wildlife South Australia. 1999. Ewens Ponds conservation park management plan: amendment to plan of management. Department for Environment, Heritage and Aboriginal Affairs, Adelaide, South Australia, Australia.

Noël, L. M.-L. J., J. N. Griffin, R. C. Thompson, S. J. Hawkins, M. T. Burrows, T. P. Crowe, and S. R. Jenkins. 2010. Assessment of a field incubation method estimating primary productivity in rockpool communities. Estuarine, Coastal and Shelf Science 88:153-159. https://doi.org/10.1016/j.ecss.2010.03.005

Nõges, P., A. Järvet, L. Tuvikene, and T. Nõges. 1998. The budgets of nitrogen and phosphorus in shallow eutrophic Lake Võrtsjärv (Estonia). Hydrobiologia 363:219-227. https://doi.org/10.1023/ A:1003165419934

Owen, C. R. 1995. Water budget and flow patterns in an urban wetland. Journal of Hydrology 169:171-187. https://doi. org/10.1016/0022-1694(94)02638-R

Paerl, H. W., and J. T. Scott. 2010. Throwing fuel on the fire: synergistic effects of excessive nitrogen inputs and global warming on harmful algal blooms. Environmental Science and Technology 44:7756-7758. https://doi.org/10.1021/es102665e

Phillips, G., O. P. Pietiläinen, L. Carvalho, A. Solimini, A. L. Solheim, and A. C. Cardoso. 2008. Chlorophyll-nutrient relationships of different lake types using a large European dataset. Aquatic Ecology 42:213-226. https://doi.org/10.1007/ s10452-008-9180-0

Reynolds, C. S. 1993. Scales of disturbance and their role in phytoplankton ecology. Hydrobiologia 249:157-171.

Reynolds, C. S. 2006. The ecology of phytoplankton. Cambridge University Press, Cambridge, U.K. https://doi.org/10.1017/ CBO9780511542145

Rigosi, A., C. C. Carey, B. W. Ibelings, and J. D. Brookes. 2014. The interaction between climate warming and eutrophication to promote cyanobacteria is dependent on trophic state and varies among taxa. Limnology and Oceanography 59:99-114. https://doi. org/10.4319/10.2014.59.1.0099

Scheffer, M., and S. R. Carpenter. 2003. Catastrophic regime shifts in ecosystems: linking theory to observation. Trends in Ecology and Evolution 18:648-656. https://doi.org/10.1016/j. tree.2003.09.002

Scheffer, M., S. R. Carpenter, M. Lenton, J. Bascompte, W. A. Brock, V. Dakos, J. van de Koppel, I. A. van de Leemput, S. A. Levin, E. H. van Nes, M. Pascual, and J. Vandermeer. 2012. Anticipating critical transitions. Science Review 338:344-348. https://doi.org/10.1126/science.1225244 
Schuyt, K. D. 2005. Economic consequences of wetland degradation for local populations in Africa. Ecological Economics 53(2):177-190. https://doi.org/10.1016/j.ecolecon.2004.08.003

Verhoeven, J. T. A., B. Arheimer, C. Yin, and M. M. Hefting. 2006. Regional and global concerns over wetlands and water quality. Trends in Ecology and Evolution 21(2):96-103. https://doi. org/10.1016/j.tree.2005.11.015

Windolf, J., E. Jeppesen, J. P. Jensen, and P. Kristensen. 1996. Modelling of seasonal variation in nitrogen retention and in-lake concentration: a four-year mass balance study in 16 shallow Danish lakes. Biogeochemistry 33:25-44. https://doi.org/10.1007/ $\underline{\mathrm{BF} 00000968}$

Wood, C. 2011. Measurement and evaluation of key groundwater discharge sites in the Lower South East of South Australia. DFW Technical Report 2011/14. Government of South Australia, through Department for Water, Adelaide, Australia.

World Bank. 2014. World Bank open data. World Bank, New York, New York, USA. [online] URL: http://data.worldbank.org/

Yin, X., and S. E. Nicholson. 1998. The water balance of Lake Victoria. Hydrological Sciences Journal 43:789-811. https://doi. org/10.1080/02626669809492173 


\section{Appendix 1. Phytoplankton Bioassay}

\section{Methodology}

A priori it was proposed that phosphorus was the limiting nutrient as the nitrate concentrations in the inflowing groundwater were 5.46-6.47 $\mathrm{mg} \mathrm{L}^{-1}$. However, bioassays were conducted to assess whether phosphorus or nitrogen was the limiting nutrient and to estimate the pelagic phytoplankton growth rate at different nutrient concentrations. Incubation experiments were performed in August 2014 during an 11 day period, using water collected from Ewens Ponds at $100 \mu \mathrm{mol} \mathrm{m}^{-2} \mathrm{~s}^{-1}$ (cool white, fluorescent lamps) with a light-dark cycle of $12 \mathrm{~h}: 12 \mathrm{~h}$, and temperature of $20^{\circ} \mathrm{C}$. As the phytoplankton concentration was close to zero a pure culture of green algae, Ankistrodesmus falcatus, was used as inoculum. The initial cell density of all treatments was adjusted to approximately 1000 cells $\mathrm{mL}^{-1}$.

In order to reduce the effect of nutrients accumulated in the cultured cells, algae were maintained in nitrate- and phosphate-free BG 11 media for five days before the experiment to deplete the intracellular store. Four nutrient treatments were used: no nitrate or phosphate added (control); Phosphorus addition comprising 100 $\mu \mathrm{mol} \mathrm{L}-1$ of $\mathrm{K}_{2} \mathrm{HPO}_{4}$; nitrogen addition as $1000 \mu \mathrm{mol} \mathrm{L}{ }^{-1} \mathrm{NaNO}_{3}$; both $\mathrm{K}_{2} \mathrm{HPO}_{4}$ and $\mathrm{NaNO}_{3}$ added at the aforementioned concentrations (N+P). Additionally, algae growth was examined using seven levels of $\mathrm{PO}_{4}{ }^{3-} \mathrm{P}$ addition $(0.1,0.2,0.5,1,2,5,10$

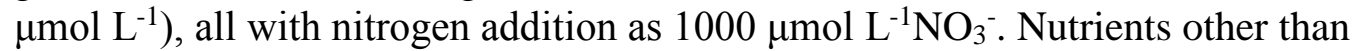
phosphorus and nitrogen for phytoplankton growth during the bioassay were provided by adding stock solutions following the formula of BG-11 media (Stanier et al., 1971).

Chlorophyll-a was measured spectrophotometrically (spectrophotometer: Libra S22 Biochrom, Cambridge, UK) from hot ethanol extracts of GF/C filtered samples. Cell counting was undertaken with an OLYMPUS BX40F4 optical microscope (Olympus, Tokyo, Japan) following standard procedures (American Public Health Association, 2005).

Phytoplankton growth rates were calculated on chlorophyll- $a$ concentration ( $\mu_{\text {Chla }}$ ) and cell numbers $\left(\mu_{c e l l}\right)$ using the following equation $\mu=\ln \left(X_{t} / X_{0}\right) / t$ where $X_{t}$ is final chlorophyll-a concentration or cell number, $X_{0}$ is initial Chl-a or cell number, and $t$ is the duration of incubation.

Nonlinear regression was used to fit growth rates with phosphate concentration following growth kinetics by Monod (1950). Statistics were performed using SPSS 19.0 (IBM, Armonk, NY, USA), and values were logarithmically transformed to meet the requirements for parametric tests when necessary. ANOVA was used to test for differences in data between cultures with variable nutrient supply patterns. Nonlinear fitting parameters were determined using OriginPro 9.0 (OriginLab, Northampton, MA, USA). 


\section{Results}

Nutrient addition to water samples significantly increased the phytoplankton cultures chlorophyll- $a$ (Chl-a) content and cell number with respect to the control $(p<0.01)$. The highest Chl-a and cell concentrations were obtained in treatments with excess phosphorus and nitrogen $(\mathrm{P}+\mathrm{N})$. The total Chl-a developed at the end of the treatment was significantly higher when adding phosphorus than nitrogen. The increase in cell number obtained with addition of $\mathrm{P}$ alone was the same as that obtained by adding both $\mathrm{P}$ and $\mathrm{N}$, showing that $\mathrm{P}$ was the controlling factor for growth (Figure A1.1).
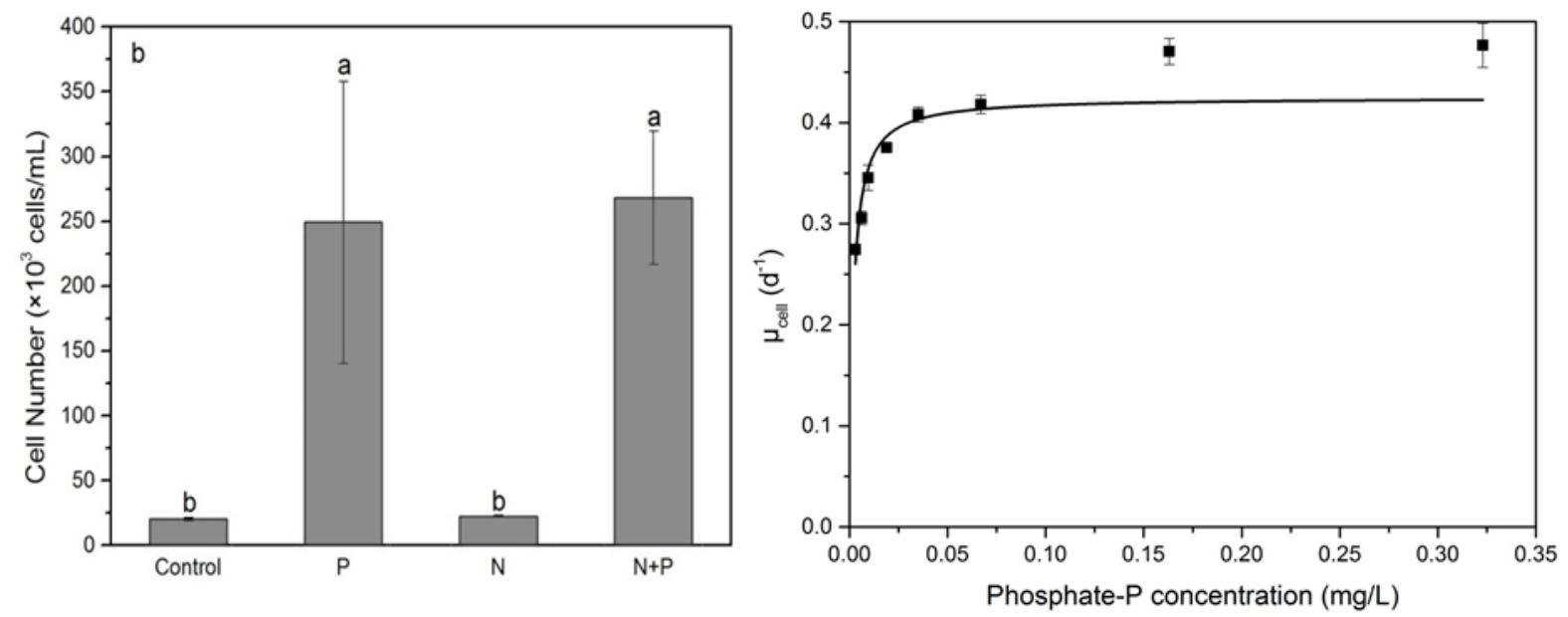

Figure A1.1 On the left, cell number at the end of the incubation experiments in samples with excess of phosphorus $(P)$, nitrogen $(N)$ and both $(P+N)$. Bars are standard deviations, columns labelled with different letters are significantly different. On the right, estimated growth rates at different phosphate concentrations.

The bioassays confirmed the initial hypothesis that phosphorus was the limiting nutrient in Ewens Ponds. Thus, one of the main factors controlling phytoplankton development is closely associated with phosphorus increase while nitrogen was present at concentrations that were excess to demand.

The second bioassay experiment allowed the estimation of phytoplankton growth rates at different $\mathrm{P}$ concentrations in the presence of excess nitrogen. Algae growth rate increased consistently until the $\mathrm{P}$ concentration reached about $0.035 \mathrm{mg}$ $\mathrm{L}^{-1}$ (Figure A1). Maximum growth rates were respectively $0.3 \mathrm{~d}^{-1}$ and $0.43 \mathrm{~d}^{-1}$ when accounting for biomass change as chlorophyll- $a$ or cell number. Half-saturation constants were respectively $0.016 \mathrm{mg} \mathrm{P} \mathrm{L}^{-1}$ for chlorophyll- $a$ and $0.019 \mathrm{mg} \mathrm{P} \mathrm{L}^{-1}$ for cell number. 


\section{References}

American Public Health Association. 2005. Standard Methods for the Examination of Water and Wastewater, 21st ed. American Public Health Association, American Water Works Association, Water Environment Federation.

Stanier, R. Y., R. Kunisawa, M. Mandel, and G. Cohen-Bazire. 1971. Purification and properties of unicellular blue-green algae (order Chroococcales). Bacteriological Reviews 35: 171-205.

Sentence Case. 


\section{Appendix 2. Raw Nutrient Results}

Table A2.1. Raw nutrient data collected in Ewens Ponds water column, groundwater inflows to the Ponds, and in bores near the Ponds (see Figure 1). Standard deviations are given in parentheses where multiple samples were collected. There was no statistical difference between samples collected in different ponds or between ponds groundwater inflow samples on a given date; therefore, these are averaged and standard deviation given.

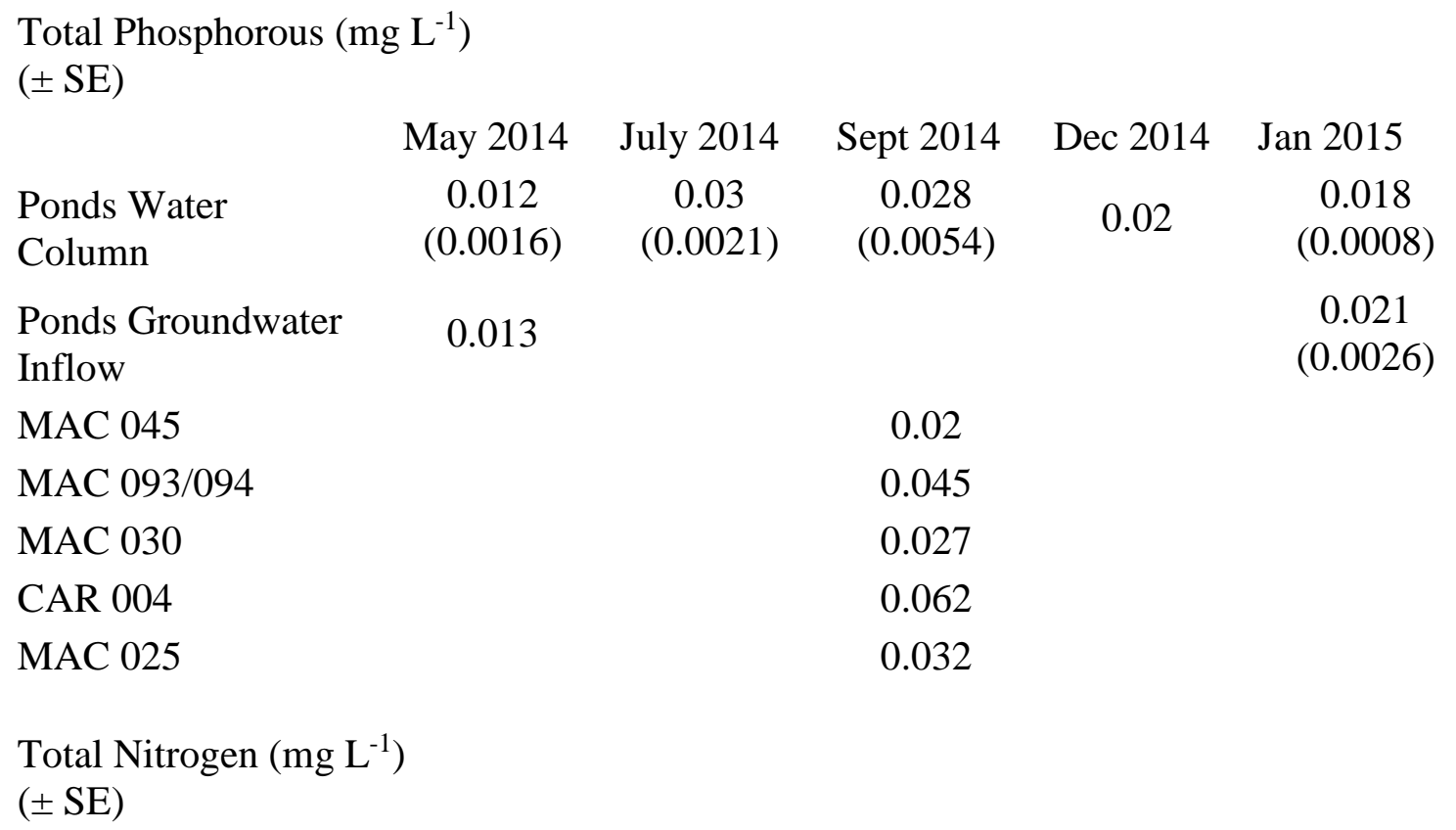

May 2014 July 2014 Sept 2014 Dec $2014 \quad$ Jan 2015

$\begin{array}{lccc}\text { Ponds Water } & 5.46 & 6.17 & 5.8 \\ \text { Column } & (0.42) & (0.34) & (0.31) \\ \text { Ponds Groundwater } & 3.9 & & \\ \text { Inflow } & (0.96) & & \\ \text { MAC 045 } & & 3.98 \\ \text { MAC 093/094 } & & 3.83 \\ \text { MAC 030 } & & 6.42 \\ \text { CAR 004 } & & 14.72 \\ \text { MAC 025 } & & 6.76\end{array}$

Sentence Case. 